
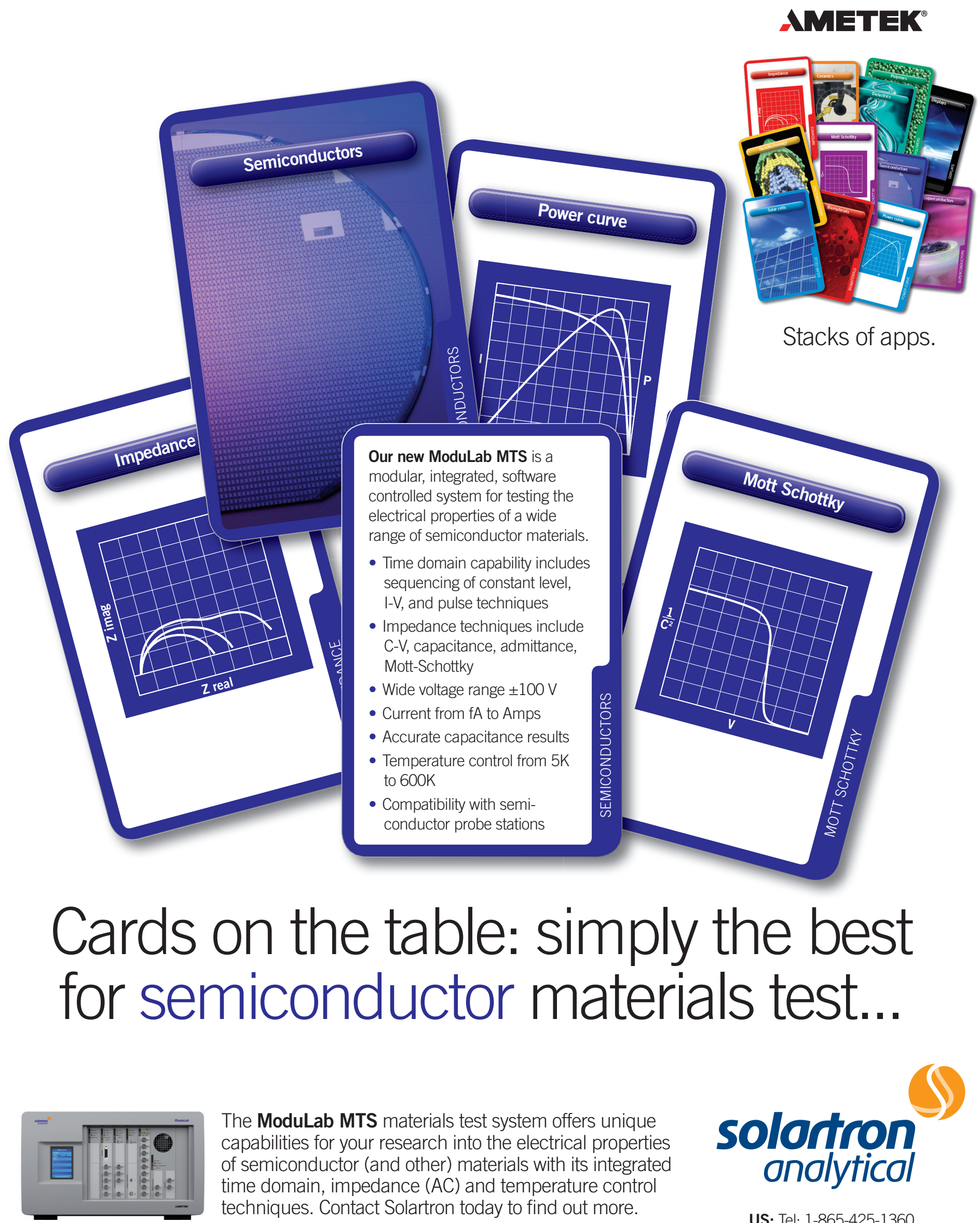

The ModuLab MTS materials test system offers unique capabilities for your research into the electrical properties of semiconductor (and other) materials with its integrated time domain, impedance (AC) and temperature control techniques. Contact Solartron today to find out more.

\section{solartron ondytical}

US: Tel: 1-865-425-1360 UK: Tel: +44 (0)1252 556800 solartron.info@ametek.com 


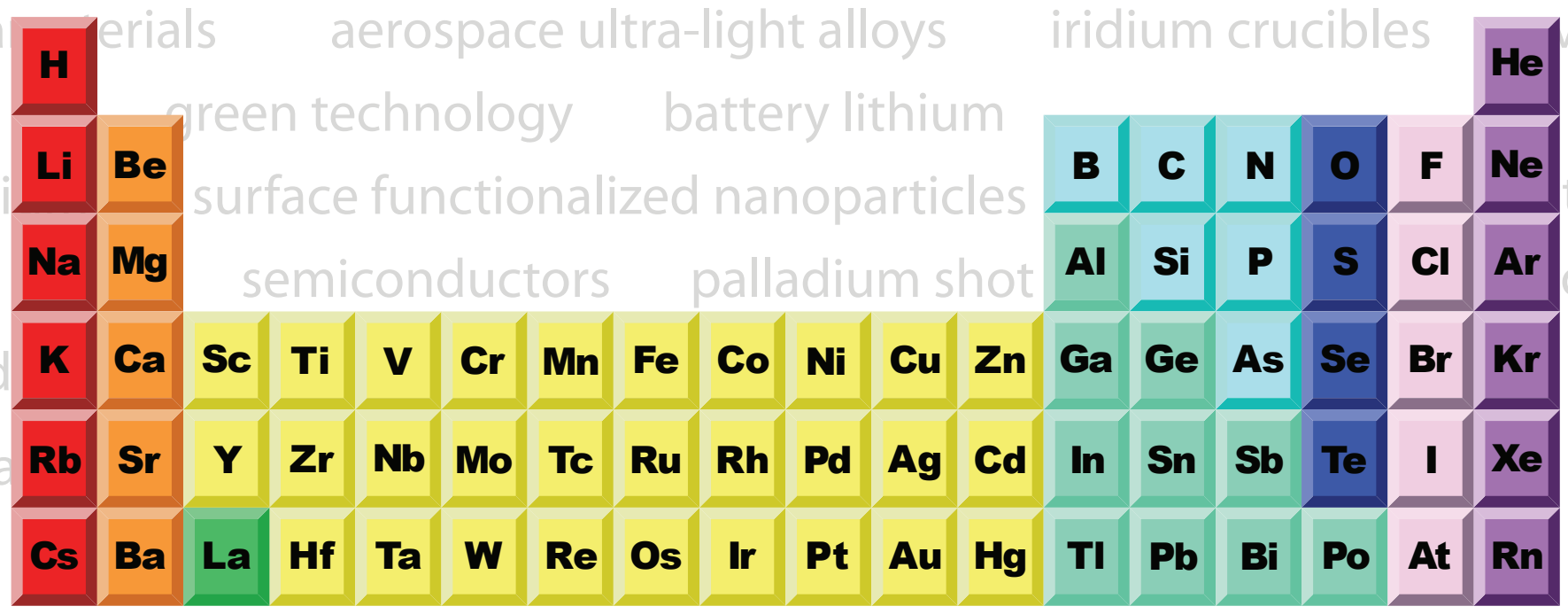

\begin{tabular}{|c|c|c|c|c|c|c|c|c|c|c|c|c|c|}
\hline Ce & Pr & Nd & Pm & Sm & Eu & Gd & Tb & Dy & Ho & Er & $\mathbf{T m}$ & $\mathbf{Y b}$ & Lu \\
\hline & $\mathbf{P}_{t}$ & $\mathbf{U}$ & Np & $\mathbf{P u}$ & Am & $\mathrm{Cm}$ & Bk & Cf & Es & $\mathbf{F m}$ & Md & No & Lr \\
\hline
\end{tabular}

europium phosphors

nanofabrics rare earth metals

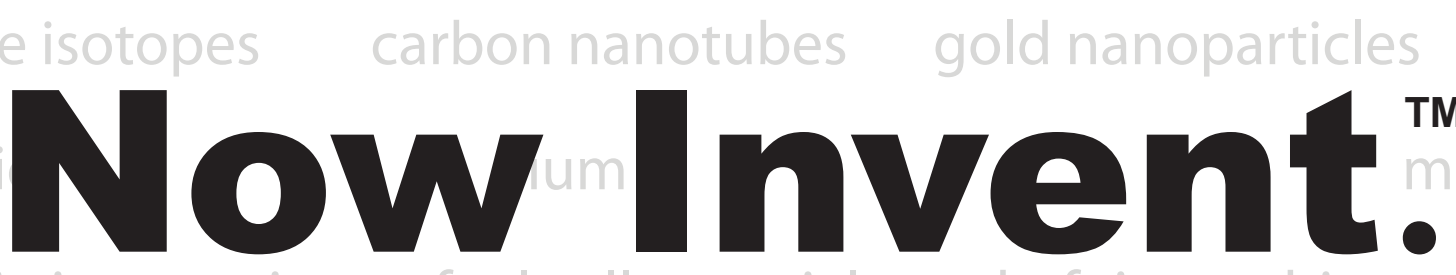

anti-ballistic ceramics fuel cell materials

germanium windows

\section{$\mathrm{E}$}

무 A E R I C A N 